\title{
Moments and number of defoliated leaves and hybrid corn productivity
}

\author{
Momentos y número de hojas defoliadas y productividad del maíz híbrido
}

\author{
J.Ramírez ${ }^{1}$, A.Soto ${ }^{1}$, C.E.Durán ${ }^{2}$,D.B. Luis ${ }^{1,3}$
}

\begin{abstract}
Objectives: To determine the effect of the time and the number of lower leaves defoliated, on the productivity of hybrid corn (Zea mays L.). Methodology: Randomized complete blocks design was used, with arrangement of split plot and four replications, using the hybrid cultivar DK 7088. The plots corresponded to the defoliation times: 0,14 and 28 days after pollination (DAP) and the subplots, number of defoliated leaves (DL): zero, two, four and six. The leaves were defoliated just below the ear, from top to the bottom. The total number of treatments was 12 . Scott-Knott statistical test with a level of $5 \%$ was used for the comparison of means. The traits studied were grain weight per ear, ear weight and grain yield per hectare. Results: The interaction between defoliation time and number of lower defoliated leaves was significant $(P<0.05)$ for grain weight per ear, ear weight and grain yield. The defoliation of two, four and six leaves during pollination reduced the grain weight per ear, weight per cob and grain yield, being significantly lower than the no defoliated plants. At 14 and 28 days after pollination, defoliation did not affect significantly $(P>0.05)$ grain yield, but grain weight per ear and ear weight decreased $(P<0.05)$. Conclusions: The defoliation of lower leaves made during the pollination, reduces the grain weight per ear, ear weight and grain yield, while defoliation 14 days after pollination did not affect significantly the grain yield per hectare.
\end{abstract}

Keywords: Zea mays, defoliation, leaves, grain yield

\section{Resumen}

Objetivos: Determinar el efecto del momento y número de hojas inferiores defoliadas, sobre la productividad del maíz (Zea mays L.). Metodología: Se utilizó el diseño de bloques completos al azar con arreglo en parcelas divididas con cuatro replicaciones, utilizando el híbrido de maíz DK 7088. Las parcelas se asignaron a los momentos de defoliación: 0,14 y 28 días después de la polinización(DDP) y las subparcelas, al número de hojas defoliadas (HD): 0, 2, 4 y 6 . Las hojas defoliadas se ubicaron por debajo de la mazorca y el conteo se hizo de arriba hacia abajo. El total de tratamientos fue de 12 y para la comparación de medias de tratamiento se utilizó la prueba estadística de Scott-Knott. Las variables estudiadas fueron peso de granos por mazorca, peso de mazorca y rendimiento. Resultados: La interacción entre los momentos de defoliación y número de hojas inferiores defoliadas fue significativa $(P<0,05)$ para peso de granos por mazorca, peso de mazorca y rendimiento. La defoliación inferior de dos, cuatro y seis hojas durante la polinización, redujo el peso de granos por mazorca, peso de mazorca y rendimiento de grano. A los 14 y 28 días después de la polinización, la defoliación no afectó significativamente $(P>0,05)$ el rendimiento de grano, pero sí el peso de granos por mazorca y el peso de la mazorca $(P<0,05)$. Conclusiones: La defoliación de hojas inferiores efectuada durante el momento de la polinización, redujo el peso de granos por mazorca, peso de la mazorca y rendimiento de grano por hectárea, mientras que las defoliaciones efectuadas 14 días después de la polinización, no afectaron significativamente el rendimiento de grano por hectárea.

Palabras clave: Zea mays, defoliación, hojas, rendimiento de grano

\section{Introduction}

In Peru, maize (Zea mays L.) is an important crop from the social and economic point of view, and ranks third in planted area. Its cultivation extends through the Costa, Sierra and Selva regions and is mainly carried out by family farmers who own less than 4.9 ha (Huamanchumo, 2013). Beside the agricultural activity, the family farmer carries out livestock activities such as the raising of cattle, sheep, guinea pigs, among others, requiring green forages to feed

\footnotetext{
${ }^{1}$ Escuela Profesional de Ingeniería Agronómica. Universidad Nacional José Faustino Sánchez Carrión, Lima, Perú.

${ }^{2}$ Universidade Federal do Espírito Santo, Espírito Santo, Brasil.

${ }^{3}$ Autor para correspondencia: dluis@unjfsc.edu.pe
} 
these animals. An alternative to feed cattle is to have the leaves of the lower third of the corn plant, as has been done in some provinces of Ecuador, but this should be used after pollination has been assured, to avoid affecting grain yield (Peñaherrera, 2011). This type of activity allows the producer to obtain the greatest benefit from the system, by producing grains and taking advantage of the green leaves that are a better quality food for livestock than the dried leaves, especially in places with forage availability problems during some part of the year (Fasae et al., 2009).

Corn is a crop of high productive potential, but sensitive to stress and with low response capacity, so defoliation turns out to be negative for the crop, because when the leaf area is reduced, less light is intercepted, photosynthesis decreases and consequently, the production of biomass is reduced. However, the magnitude of the damage will depend on the moment in which it occurs and on the tolerance of the genetic material to defoliation (Sangoi et al., 2014b). When defoliation occurs during female flowering, a reduction in yield is caused, and the magnitude being dependent on the position of the leaves (Ospina, 2015). Similarly, when defoliation occurs very close to flowering, there is a significant reduction in yield as a consequence of the reduction in length, weight of ear and weight of grains per ear (Roma et al., 2012; Dias et al., 2013).

Aparecida et al. (2011) reported that with the elimination of six lower leaves in the pollination stage, the yield was reduced by $33 \%$ with respect to the control. Similar result was evidenced by Tavares et al. (2016) that, with the elimination of the lower leaves, the yield was reduced by $37 \%$.

In this context, this research aimed to evaluate the productivity of the corn hybrid DK 7088, in relation to the moments of defoliation and the number of defoliated leaves.

\section{Methodology}

The research was conducted in field conditions between the months of November 2012 and March 2013, in the province of Barranca, Lima, coordinates $10^{\circ} 46^{\prime} 43^{\prime \prime}$ south latitude, $77^{\circ} 45^{\prime} 11^{\prime \prime}$ west longitude, altitude of 5 masl. The temperature ranged between 15 and $26^{\circ} \mathrm{C}$.

According to the analysis of the soil, carried out by the Soil laboratory of Instituto de Investigación Agraria-Donoso, Huaral, soil was characterized by texture sandy loam texture, electrical conductivity (EC) of $5.11 \mathrm{mS} \mathrm{cm}$; $\mathrm{pH} 6.9$; cation exchange capacity (CEC) $11.34 \mathrm{cmolc} \mathrm{kg}^{-1} ; 2.57 \%$ organic matter; $\mathrm{N} 0.13 \%$; K $130 \mathrm{mg} \mathrm{kg}^{-1}$; $\mathrm{P} 4 \mathrm{mg} \mathrm{kg}^{-1}$ and calcium carbonate (CaCO3) $0.44 \%$.

Planting date for the simple corn hybrid DK 7088 was carried out in the first week of November 2012. The distance between rows and hills was 0.80 and $0.33 \mathrm{~m}$, respectively. Four seeds were placed each hill, leaving two plants per hill after 15 days, with a final population of 75757 plants per hectare. The conduction of the experiment corresponded to conventional agronomic management. The fertilizer formula $180-120$ - 100 was used and the sources were urea $(46 \% \mathrm{~N})$, diammonium phosphate $(18 \%$ $\left.\mathrm{N}, 46 \% \mathrm{P}_{2} \mathrm{O}_{5}\right)$ and potassium chloride $\left(60 \% \mathrm{~K}_{2} \mathrm{O}\right)$, applications being made at 15 and 45 days after sowing, just nitrogen being fractioned. For weed control, pre-emergent application of atrazine herbicide was carried out at a rate of $0.5 \mathrm{~L}$ ha- 1 , one week after sowing, then two manual weeding was done. For the control of Spodoptera frugiperda five alternating applications were made with chlorpyrifos and methomil, and for tar spot (Phyllachora maydis), two applications of chlorothalonil were made.

The harvest was manual and carried out 140 days after sowing. For grain yield $\left(\mathrm{t} \mathrm{ha}^{-1}\right)$, the two central rows were harvested; corrections for faults in the field and grain humidity to $14 \%$, were made.

The experimental design used was randomized complete blocks under split plot arrangement, with 12 treatments and four replications. The plots were assigned to the moments of defoliation: 0,14 and 28 days after pollination (DAP) and the sub-plots were assigned to the number of defoliated leaves (DL): zero, two, four and six. The experimental unit consisted of four rows and the net area per plot was $12.8 \mathrm{~m}^{2}$. The application of the treatments was carried out from female flowering (R1 stage), carefully as not to harm the number of grains per ear (Aparecida et al., 2011), considering it as zero day (0 DAP). The following defoliations were made 14 and 28 days later. The defoliation was carried out below the main ear, beginning from top to bottom. The leaves were removed manually and carefully so as not to damage the ears.

The data obtained were subjected to the analysis of variance and the comparison of means was made by the Scott-Knott test, with a significance level of 5 $\%$. Data were processed with statistical program SISVAR (Furtado, 2011).

\section{Results and discussion}

According to the analysis of variance, for weight of grains per ear, weight of the ear and grain yield per hectare, significant interactions were observed $(P<0.05)$ between the moments of defoliation and the 
number of defoliated leaves. Considering there was interaction between moments and number of defoliated leaves for weight of grains per ear, weight of ear and grain yield per hectare, further analysis was made for the crossed effects between both factors under study.

Figures 1 and 2 show that defoliation of two, four and six lower leaves made during pollination (0DAP), significantly affected both the weight of grains per ear and the weight of the ear. Likewise, it can be observed that the defoliation of two and four lower leaves made at 14 and 28 days after the pollination, produced similar weights of grains per ear and weight of ear, in relation to the control treatment (not defoliated); while the defoliation of six lower leaves made in the same moments, affected significantly $(P<0.05)$ both the weight of grains per ear and the weight of the ear. The weights of grains per ear and ear weight obtained at defoliation times 14 and 28 days after the pollination, were significantly higher $(P<0.05)$ in relation to early defoliation(0 DAP).

Decrease in the weight of grains per ear and ear weight, produced by an early defoliation ( $0 \mathrm{DAP})$, is explained because at that moment the plant is reaching its maximum development of the photosynthetic foliar area. As long as it remains more active, the higher the productivity, so a reduction in foliar area will affect the redistribution of photoassimilates within the plant (Tavares et al., 2016).

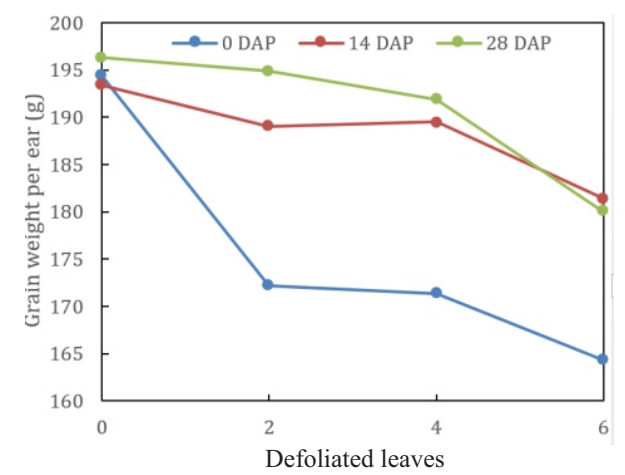

Figure 1. Grain weight per ear (g) as affected to the times and number of defoliated leaves in the hybrid corn DK 7088.

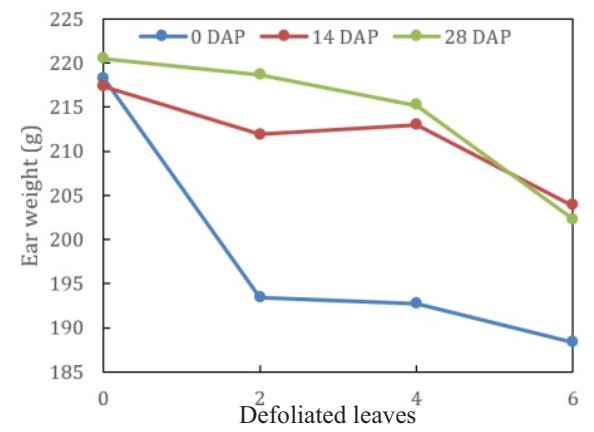

Figure 2. . Ear weight ( $\mathrm{g}$ ) as affected to the times and number of defoliated leaves in hybrid corn DK 7088.
In the case of grain yield per hectare, it was observed that defoliation during pollination significantly affected this character $(P<0.05)$; defoliation of the lower leaves of maize after 14 days had no significant effect on grain yield per hectare (Figure 3). The greatest yield reductions occurred when four and six lower leaves were removed during pollination (0 DAP) compared to the defoliation of two lower leaves; this reduction was not significant when defoliation was carried out after 14 days of pollination.

This results could indicate that, given the decrease in the photosynthetic surface, the contribution of carbohydrates would come from the stem (Tavares et al., 2016) and from the upper leaves that remain active during the filling of the grains (Roma et al., 2012), that are responsible for about 80 $\%$ of the carbohydrates accumulated in the grains (Dias et al., 2017). In the case of control treatment (not defoliated), the reduction of the photosynthetic activity of the lower leaves due to the decrease in luminosity has occurred (Pérez et al., 2013), or the loss of leaf area as a consequence of the natural senescence, nitrogen deficiency or attack of diseases (Lima et al., 2010). Queiróz et al. (2015) indicate that the leaves of the lower third provide energy supply for the root system, while the middle and upper third supply energy to the morphological and reproductive structures.

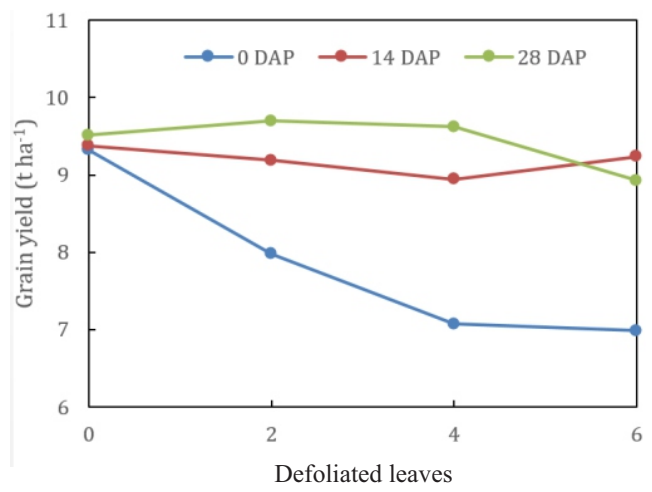

Figure 3. Grain yield $\left(\mathrm{t} \mathrm{ha}^{-1}\right)$ as affected by the times and number of defoliated leaves in the hybrid corn DK 7088.

Despite the observed reduction in yield due to defoliation, it was lower than that found by Aparecida et al. (2011) and Tavares et al. (2016); the obtained results corroborate what affirmed by Mota et al. (2010) and Santos et al. (2015), who stated that this phase is critical and that the maintenance of leaf integrity is important because this is the main organ responsible for the photosynthesis and production of 
the photosynthates that are moved to the storage sites; in addition, corn plant presents a low compensation capacity. Kappes et al. (2011) reaffirm the above, when mentioning that during the reproductive period, the integrity of the leaf area is fundamental both for the expression of the yield potential of the crop and for the maintenance of stem integrity, avoiding plant lodging.

Sangoi et al. (2014a), reported that defoliation in the phase of male flowering significantly reduces yield and that they cannot be recovered with the application of nitrogen, because corn corresponds to a determined habit of growth and does not develop new leaves that can continue to supply from photosynthates to storage organs.

Lima et al. (2010) evaluating the defoliation above and below the ear in four reproductive stages, showed that the yields obtained were lower than the non-defoliated treatment and that defoliation of basal leaves produced higher yields in relation to defoliation of upper leaves. Similar results was obtained by Ferreira et al. (2016), who showed that the increase in the number of defoliated leaves, during R1 stage, directly affects the reduction of yield.

The results obtained allow us to infer that after 14 days of pollination, the defoliation of basal leaves would not have a negative impact on the grain yield, as evidenced by Cabada \& Ahumada (2016) who, evaluating moments and intensity of defoliation, found defoliation in a 50 and $100 \%$ of the plant at 20 and 40 days after pollination, did not cause significant reduction in yield, compared to the control without defoliation. Similar result were reported by Fasabe et al. (2009) who did not find significant differences for yield between treatments with defoliation made at 12 and 16 weeks after sowing compared with nondefoliated plants.

\section{Conclusions}

According to the conditions in which the research was developed, it can be concluded that defoliation of two, four and six leaves, made during the pollination of corn hybrid DK 7088, significantly reduced the weight of grains per ear, ear weight and grain yield per hectare, while defoliations carried out at 14 and 28 days after pollination did not affect grain yield per hectare. With these findings, it is possible to establish an adequate time for the defoliation of the lower leaves in corn, starting 14 days after pollination and with the elimination up to six leaves per plant, without significantly affecting the grain yield.

\section{Referencias}

Aparecida, C., Fillwock, J. \& Suzin, V. (2011). Efeito do desfolhamento das plantas na produtividade do milho. Revista Brasileira de Tecnologia Aplicada nas Ciências Agrárias, 4(3), 179-190.

Cabada, S. \& Ahumada, M. (2016). Incidencia del daño foliar sobre el rendimiento del cultivo de maíz (Zea mays). Serie Extensión INTA Paraná, 79, 13-17.

Dias, A., Calves, T., Carlos, L., Maraschi, L. \& Luiz, M. (Noviembre de 2013). Efeito da desfolha da planta do milho nos componentes de produtividade. En G. Ceccon (Presidente), Estabilidade e Produtividade. Trabajo presentado en el XII Seminário Nacional de Milho Safrinha, Mato Grosso do Sul, Brasil.

Dias, J., Otto, S., Alves, C. \& Schanz, C. (2017). Doses de adubação nitrogenada em cobertura submetido a dois níveis de desfolha no milho safrinha na amazônia ocidental. Agrarian academy, 4(7), 192.

Fasae, O., Adu, F., Aina, A. \& Elemo, K. (2009). Los efectos del tiempo de defoliación en el rendimiento, calidad y almacenamiento de las hojas de maíz como forraje estacional para la producción de rumiantes. Revista Brasileira de Ciencias Agrarias, 4(3), 353-357.

Ferreira, L., Trogello, E., Ferreira, B., Antonio, J., Ferreira, R. \& Araújo, F. (Septiembre de 2016). Características agronômicas do milho em função de diferentes níveis de desfolha artificial. En A. Gomes (Presidente), Ciencia e tecnología: produção sustentável e segurança alimentar. Trabajo presentado en el V Congresso Estadual de Iniciação Científica e Tecnológica, Goiás, Brasil.

Furtado, D. (2011). A Computer statistical Analysis System. Ciência e Agrotecnologia, 35, 10391042.

Huamanchumo, C. (2013). La cadena de valor de maíz en el Perú: Diagnóstico del estado actual, tendencias y perspectivas. Lima: IICA.

Kappes, C., Andrade, J., Arf, O., Oliveira, A., Arf, M. \& Ferreira, J. (2011). Arranjo de plantas para diferentes híbridos de milho. Pesquisa Agropecuaria Tropical Goiãnia, 41(3), 348-359.

Lima, T., Von Pinho, R., Rezende, J., Brito, A. \& Von Pinho, E. (2010). Consequências da remoção do limbo foliar em diferentes estádios reprodutivos da cultura do milho em duas épocas de semeadura. Bragantia, 69(3), 563-570. 
Mota, M., Cardoso, J., Ribeiro, I., Vieira, G. \& Luis, F. (2010). Épocas de aplicação de nitrogênio em cobertura na cultura do milho em plantio direto, e alocação de nitrogênio $\left({ }^{15} \mathrm{~N}\right)$ na planta. Revista Brasileira de Ciência do Solo, 34(4), 1185-1194.

Ospina, J. (2015). Manual técnico del cultivo de maíz bajo buenas prácticas agrícolas. Medellín, Colombia: Fotomontajes S.A.S.

Peñaherrera, D. (2011). Manejo integrado del cultivo de maíz de altura. Módulos de Capacitación para Capacitadores. Módulo 4. Quito, Ecuador: Instituto Nacional Autónomo de Investigaciones Agropecuarias.

Pérez, A., Bustamante, E., Vélez, L. \& Cotes, J. (2013). Acumulación y distribución de fitomasa en el asocio de maíz (Zea mays L.) y fríjol (Phaseolus vulgaris L.). Revista Facultad Nacional de Agronomía Medellín, 66(1), 68656880.

Queiróz, V., Carvalho, I., Follmann, D., Nardino, M., Bellé, R., Baretta, D. \& Schmidt, D. (2015). Desfolhamento artificial e seus efeitos nos caracteres morfológicos e produtivos em híbridos de milho. Revista Brasileira de Milho e Sorgo, 14(1), 61-74.
Roma, M., Biazotti, E., Garcia, A., Lima, R., Santos, K. \& Ferreira, M. (2012). Características morfoagronômicas do milho submetido a diferentes níveis de desfolha manual. Ceres, 59(2), 200-205.

Sangoi, L., Junior, G., Vargas, V., Vieira, J., Schmitt, A., Zoldan, S., Siega, E. \& Carniel, G. (2014a). Cobertura nitrogenada como estratégia para reduzir os prejuízos da desfolha em diferentes estádios fenológicos do milho. Semina: Ciências Agrárias, 35(2), 671-682.

Sangoi, L., Vieira, J., Schenatto, D., Giordani, W., Boniatti, C., Dalligna, L., Souza, C. \& Zanella, E. (2014b). Tolerância à desfolha de genótipos de milho em diferentes estádios fenológicos. Revista Brasileira de Milho e Sorgo, 13(3), 300311.

Santos, W., Brito, C., Brandão, A., Faria, C., Viana, M. \& Siqueira, A. (2015). Desenvolvimento e produtividade de grãos de milho submetido a níveis de desfolha. Pesquisa Agropecuaria Brasileira, 50(3), 203-209.

Tavares, P., Mourão, A. \& Beal, C. (2016). Efeito da desfolha de plantas de milho sobre parâmetros produtivos. Acta Iguazu, 5(2), 94-101. 